\title{
Respon Pertumbuhan dan Hasil Padi Hitam (Oryza sativa L) Lokal Banyuwangi terhadap Aplikasi Beberapa Jenis Pupuk Kandang
}

\author{
The Growth and Yield Responses of Banyuwangi Local Black Rice (Oryza sativa L) \\ to Manures Application
}

\author{
Author(s): Ari Istanti( ${ }^{(1) *}$; Diyah Triasih ${ }^{(1)}$ \\ (1) Politeknik Negeri Banyuwangi \\ * Corresponding author: ari.istanti@poliwangi.ac.id
}

\begin{abstract}
ABSTRAK
Beras hitam merupakan varietas lokal yang mengandung pigmen paling baik, memiliki rasa dan aroma yang baik dengan penampilan yang spesifik dan unik. Beras hitam masih jarang dibudidayakan dan dikonsumsi oleh masyarakat dikarenakan banyak masyarakat yang belum familiar tentang beras hitam, umur tanam padi hitam yang lebih panjang dibandingkan padi putih (bisa mencapai 5-6 bulan), dan produktivitasnya yang lebih rendah dibandingkan padi putih. Salah satu upaya yang dapat dilakukan untuk meningkatkan kuantitas padi hitam adalah dengan pemupukan, baik organik maupun anorganik. Penelitian ini bertujuan untuk mengidentifikasi jenis dan taraf pupuk organik terbaik yang didapatkan dari pupuk kandang untuk dapat meningkatkan pertumbuhan dan hasil beras hitam. Penelitian ini menggunakan Rancangan Acak Lengkap (RAL) 2 faktor yaitu jenis pupuk kandang dan taraf pupuk kandang. Pupuk kandang yang digunakan yaitu pupuk kandang ayam, pupuk kandang sapi, dan pupuk kandang kambing. Taraf pupuk kandang yang digunakan adalah $0 \%(0 \mathrm{~g}), 50 \%(6,25 \mathrm{~g}), 100 \%$ $(12,5 \mathrm{~g}), 150 \%$ (18,75 g), 200\% (25 g), dan 250\% (31,25 g) dengan tiga ulangan. Perlakuan pupuk kandang kambing sebanyak 18,75 g mampu meningkatkan kandungan klorofil hingga 2,67 mg/g.
\end{abstract}

\section{Kata}

Kunci:

Hitam Melik

Banyuwangi;

Padi organik;

Pertumbuhan; Pupuk kandang

\section{Keywords:}

Hitam Melik

Banyuwangi;

Growth;

Manure;

Organic rice

\section{ABSTRACT}

Black rice is a local variety that contains the best pigment, has a good taste and aroma with a specific and unique appearance. Black rice is still rarely cultivated and consumed by people because they are not familiar with black rice; the cultivation period of black rice is longer than white rice (can reach 5-6 months), and its productivity is lower than white rice. One way to increase the quantity of black rice is by fertilization, both organic and inorganic. This study aimed to identify the best type and level of organic fertilizers (obtained from manures) to increase the growth and yield of black rice. This study was conducted using a Completely Randomized Design (CRD) with 2 factors, which were the type and the level of manure. The manure used was chicken manure, cow manure, and goat manure. The levels of manure used were $0 \%(0 \mathrm{~g}), 50 \%$ (6.25 g), $100 \%$ (12.5 g), $150 \%$ (18.75 g), 200\% (25 g), and 250\% (31.25 g) with 3 replications. The goat manure treatment $(18.75 \mathrm{~g})$ was able to increase the chlorophyll content up to $2.674 \mathrm{mg} / \mathrm{g}$. 


\section{PENDAHULUAN}

Beras hitam merupakan sumber pangan lokal yang kaya akan antioksidan. Beras hitam merupakan varietas lokal yang mengandung pigmen paling baik, memiliki rasa dan aroma yang baik dengan penampilan yang spesifik dan unik (Suardi \& Ridwan, 2009). Beras hitam mempunyai kandungan serat pangan (dietary fiber) dan hemiselulosa masingmasing sebesar 7,5\% dan 5,8\%, sedangkan beras putih hanya sebesar $5,4 \%$ dan 2,2\% (Sa'adah et al., 2013). Beras putih agak transparan hanya memiliki sedikit aleuron dan mengandung amilosa sekitar 20\% (Suardi \& Ridwan, 2009).

Beras hitam banyak dimanfaatkan oleh masyarakat sebagai pangan pokok sehat, terutama beras hitam organik. Sayangnya, tingginya kandungan nutrisi yang dimiliki oleh beras hitam tidak diimbangi dengan ketersediaan beras hitam yang cukup di pasaran. Beras hitam masih jarang dibudidayakan dan dikonsumsi oleh masyarakat dikarenakan banyak masyarakat yang belum familiar tentang beras hitam, umur tanam padi hitam yang lebih panjang dibandingkan padi putih (bisa mencapai 5-6 bulan), dan produktivitasnya yang lebih rendah dibandingkan padi putih. Menurut Suardi \& Ridwan (2009), varietas Cempo Ireng mampu berproduksi 4,5 t/ha dan sudah dapat dipanen ketika umur 5 bulan, sedangkan varietas IR64 mampu mencapai produksi 6 t/ha dengan umur panen hanya 4 bulan (Kementerian Pertanian, 2018).

Salah satu upaya yang dapat dilakukan untuk meningkatkan kuantitas padi hitam adalah dengan pemupukan, baik organik maupun anorganik. Perbedaan unsur hara makro dan mikro yang terkandung di dalam pupuk organik mampu mempengaruhi proses vegetatif dan generatif serta kualitas tanaman padi hitam (Gangmei \& George, 2017; Yuniarti et al., 2017).
Berdasarkan permasalahan di atas, maka perlu dilakukan studi peningkatan kualitas dan kuantitas beras hitam dengan penambahan bahan organik. Penelitian ini bertujuan untuk mengidentifikasi jenis dan taraf pupuk organik terbaik yang didapatkan dari pupuk kandang untuk dapat meningkatkan pertumbuhan dan hasil beras hitam

\section{METODOLOGI}

Penelitian ini dilakukan akhir Juli hingga akhir Oktober 2020 bertempat di screen house. Proses percobaan terdiri dari beberapa tahapan sebagai berikut :

\section{Pembibitan}

Benih padi Hitam Melik dikecambahkan dalam kertas tisu lembab selama 3 hari. Benih yang sudah berkecambah disemaikan di pot tray dengan media top soil + pupuk kandang selama 2 minggu.

2. Persiapan media tanam dan aplikasi pupuk kandang

Tanah top soil ditimbang seberat $11,7 \mathrm{~kg}$ (menyesuaikan kedalamn perakaran padi dengan tinggi polibag) lalu dimasukkan ke dalam ember. Pupuk kandang ditimbang sesuai dengan masingmasing perlakuan lalu dicampurkan dengan tanah top soil secara merata. Media yang sudah tercampur selanjutnya dimasukkan ke dalam polibag. Kemudian dilakukan pemberian label sesuai masingmasing kode perlakuan. Media didiamkan selama 2 hari sebelum tanam sesuai dengan (Marwanto et al., 2018).

\section{Pemupukan}

Media yang sudah didiamkan selama 2 hari kemudian diaplikasikan pupuk kimia sebagai pupuk dasar sesuai dengan anjuran Permentan tentang Rekomendasi Pemupukan N, P, Dan K Pada Padi Sawah Spesifik Lokasi Tahun 2007 yaitu 275 kg/ha urea, 100 kg SP-36, 
dan $100 \mathrm{~kg} / \mathrm{ha} \mathrm{KCl}$. Taraf pupuk kimia dasar diberikan sama untuk semua perlakuan. Pemupukan dilakukan dalam 2 tahap. Pemupukan tahap 1 diaplikasikan ketika awal tanam sebanyak $2 / 3$ urea dan seluruh SP36 dan KCl. Pemupukan tahap 2 diaplikasikan menjelang berbunga dengan $1 / 3$ dosis urea.

\section{Penanaman dan perawatan}

Bibit padi hitam yang siap pindah tanam ditanam di media tanam yang sudah disiapkan dengan 2 bibit per polibag dan jarak tanam antar plot adalah 1 meter. Di bawah polibag diberi ember untuk menahan air dan menjaga agar pupuk kandang tidak bercampur dengan perlakuan lain. Penanaman padi hitam dilakukan di dalam screen house. Pemberian air pada tanaman disesuaikan dengan kebutuhan tanaman. Pemberantasan hama dan penyakit dilakukan sesuai kebutuhan di lapang.

Penelitian ini dirancang menggunakan metode Rancangan Acak Lengkap (RAL) 2 faktor yaitu jenis pupuk kandang dan taraf pupuk kandang. Pupuk kandang yang digunakan yaitu pupuk kandang ayam (A), pupuk kandang sapi $(\mathrm{S})$, dan pupuk kandang kambing $(\mathrm{K})$. Dosis dasar pupuk kandang yang digunakan mengacu pada rekomendasi Permentan (2007) yaitu $2 \mathrm{t} / \mathrm{ha}$. Taraf pupuk kandang yang digunakan adalah T0 $=0 \%(0 \mathrm{~g}), \mathrm{T} 1=50 \%(6,25 \mathrm{~g}), \mathrm{T} 2=$ $100 \%(12,5 \mathrm{~g}), \mathrm{T} 3=150 \%(18,75 \mathrm{~g}), \mathrm{T} 4=$ $200 \%(25 \mathrm{~g})$, dan $\mathrm{T} 5=250 \%(31,25 \mathrm{~g})$ dengan total 18 perlakuan (AT0, AT1, AT2, AT3, AT4, AT5, ST0, ST1, ST2,
ST3, ST4, ST5, KT0, KT1, KT2, KT3, KT4, KT5) dengan tiga ulangan. Pengamatan terhadap parameter laju pertumbuhan dilakukan sesudah 1 minggu tanaman mendapatkan respon perlakuan hingga tanaman memasuki fase reproduktif. Pengamatan kandungan kolorofil dilakukan ketika tanaman berumur 1 bulan menggunakan spektrofotometer. Pengamatan hasil tanaman dilakukan ketika panen dengan menghitung jumlah anakan produktif dan menimbang berat kering gabah. Data hasil pengamatan dan pengujian dianalisis dengan ANOVA dan apabila terdapat perbedaan yang nyata dilanjutkan dengan uji Duncan 5\%.

\section{HASIL DAN PEMBAHASAN}

Berdasarkan data yang didapatkan dari percobaan di lapang, diperoleh hasil $\mathrm{F}$ hitung variabel pengamatan seperti yang tercantum dalam Tabel 1. Tabel 1 menunjukkan bahwa aplikasi pupuk kandang memberikan hasil yang berbeda tidak nyata terhadap variabel pengamatan laju pertumbuhan dan berat gabah padi hitam, baik secara tunggal maupun interaksi. Sedangkan variabel kandungan klorofil menunjukkan hasil yang berbeda sangat nyata, baik secara tunggal maupun interaksi kedua faktor. Hasil F hitung yang diperoleh mengindikasikan bahwa aplikasi pupuk kandang mempengaruhi respon pertumbuhan tanaman secara fisiologis, namun belum mampu memberikan hasil yang signifikan untuk hasil berat gabah tanaman padi hitam. 
Tabel 1. Rangkuman F-hitung Pengaruh Aplikasi Pupuk Kandang Terhadap Variabel Pengamatan Pertumbuhan dan Hasil Padi Hitam Melik

Table 1. The F-count Summary of Manures Application Effect for Hitam Melik Black Rice's Gowth and Yield Observation Variables

\begin{tabular}{ccccc}
\hline \multirow{2}{*}{$\begin{array}{c}\text { No. } \\
\text { (No.) }\end{array}$} & $\begin{array}{c}\text { Variabel Pengamatan } \\
\text { (Observation Variables) }\end{array}$ & $\begin{array}{c}\text { Jenis Pupuk } \\
\text { (Type of } \\
\text { Manures) }\end{array}$ & $\begin{array}{c}\text { Taraf Pupuk } \\
\text { (Level of } \\
\text { Manures) }\end{array}$ & $\begin{array}{c}\text { Jenis x Taraf } \\
\text { Pupuk } \\
\text { (Type x Level of } \\
\text { Manures) }\end{array}$ \\
\hline 1 & $\begin{array}{l}\text { Laju Pertumbuhan (Gowth } \\
\text { rate) }\end{array}$ & $0,77^{\mathrm{tn}}$ & $1,24^{\mathrm{tn}}$ & $1,09^{\mathrm{tn}}$ \\
\hline 2 & $\begin{array}{l}\text { Berat Gabah (Gain } \\
\text { Weight) }\end{array}$ & $0,71^{\mathrm{tn}}$ & $0,95^{\mathrm{tn}}$ & $1,23^{\mathrm{tn}}$ \\
\hline 3 & Klorofil (Chlorophyll) & $50254,55^{* *}$ & $42778,65^{* *}$ & $29705,99^{* *}$ \\
\hline
\end{tabular}

Keterangan:

$* *$ = berbeda sangat nyata (very significantly different)

* = berbeda nyata (significantly different)

tn $=$ berbeda tidak nyata (non significantly different)

Laju pertumbuhan tanaman padi hitam menunjukkan hasil yang berbeda tidak nyata akibat aplikasi pupuk kandang, namun Gambar 1 menunjukkan bahwa pertambahan laju pertumbuhan tanaman padi hitam menunjukkan kecenderungan khusus pada masing-masing pupuk kandang yang digunakan.

a

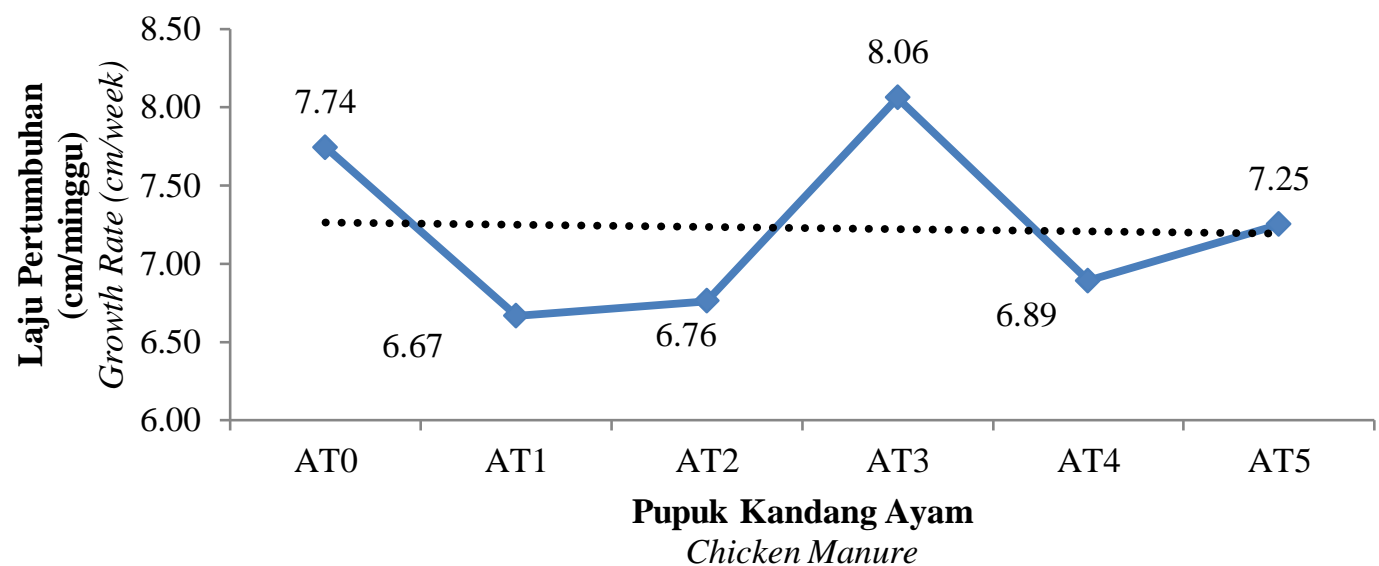

b

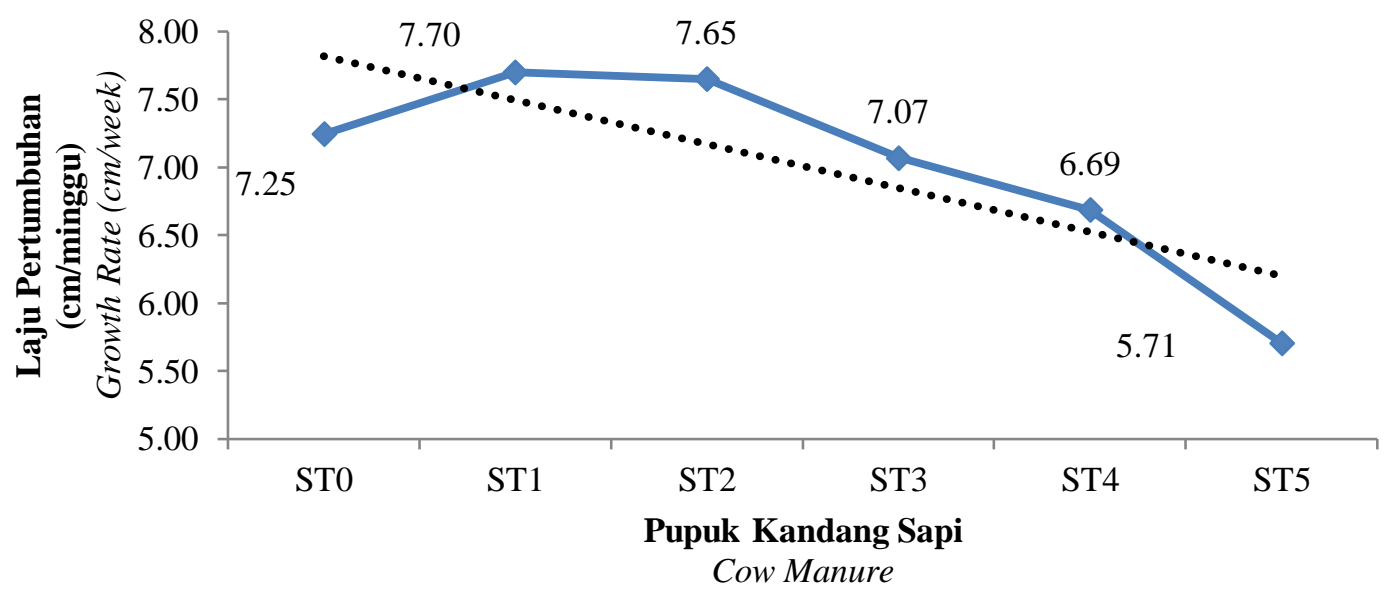




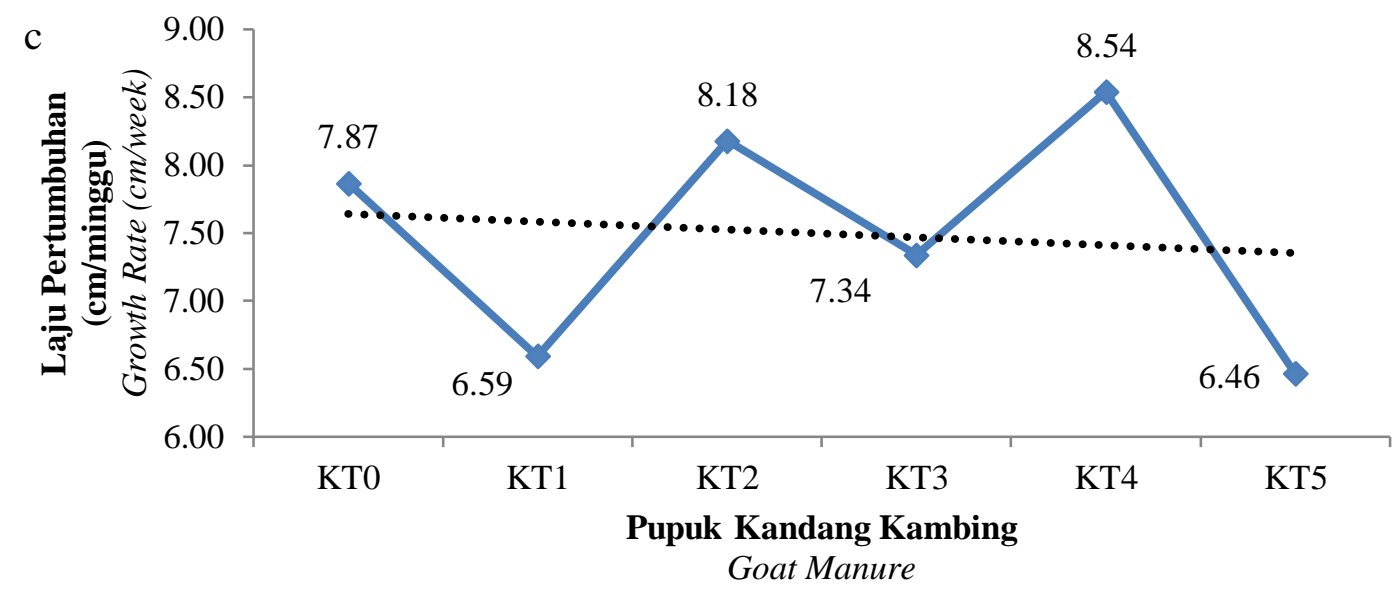

Keterangan :

Garis putus-putus menunjukkan kecenderungan laju pertumbuhan akibat aplikasi pupuk kandang (The dotted line showed the trend line of gowth rate due to manure application)

Gambar 1. Pengaruh Aplikasi Pupuk Kandang Terhadap Laju Pertumbuhan Tanaman Padi Hitam Melik

Figure 1. Effect of Manures Application on Gowth Rate of Hitam Melik Black Rice

Gambar 1 menunjukkan bahwa laju pertumbuhan tanaman padi hitam cenderung mengalami penurunan seiring meningkatnya taraf pupuk kandang yang diberikan, terutama pada pupuk kandang sapi. Hal ini diduga disebabkan oleh rendahnya kandungan $\mathrm{C} / \mathrm{N}$ rasio yang terdapat dalam pupuk kandang sapi $(4,549 \%)$ dibandingkan pupuk kandang yang lain (15\%) sehingga nitrogen yang tersedia tidak dapat diasimilisasi oleh tanaman. Sedangkan nitrogen yang terdapat dalam pupuk kandang sapi paling rendah dibandingkan pupuk kandang yang lain $(0,870 \%)$, sehingga meskipun dosis pupuk kandang sapi ditingkatkan, asimilasi nitrogen tidak berjalan lancar dan menyebabkan rendahnya laju pertumbuhan tanaman padi hitam (Istanti \& Triasih, 2020)

Pemberian nitrogen secara langsung mempengaruhi sintesis karbohidrat di sel tanaman. Nitrogen berperan sebagai pembentuk klorofil yang menyebabkan daun tanaman berwarna hijau (Damanik et al., 2010). Dalam penelitian ini dapat diamati pengaruh nutrisi yang terkandung dalam pupuk kandang terhadap kandungan klorofil tanaman padi hitam selain terhadap laju pertumbuhan tanaman. Aplikasi pupuk kandang memberikan hasil yang berbeda sangat nyata baik secara tunggal maupun interaksi keduanya (Tabel 1). 


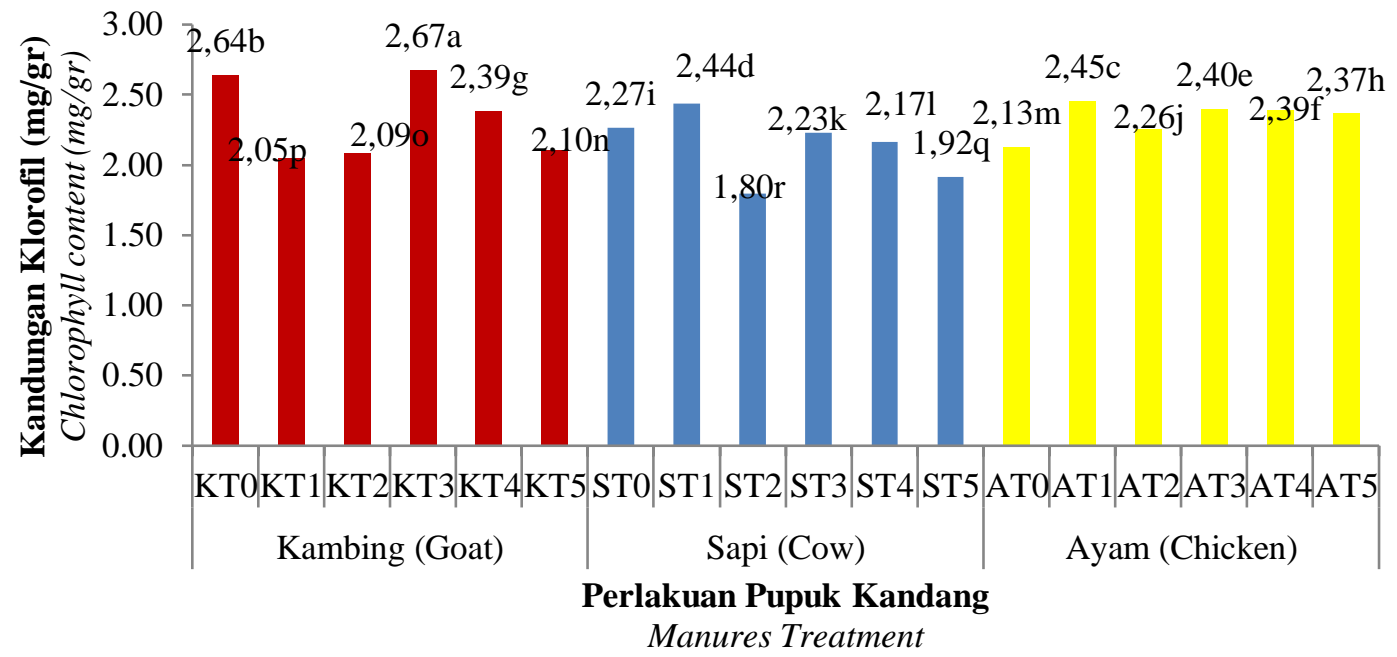

Keterangan :

Angka yang diikuti huruf yang sama menunjukkan berbeda tidak nyata pada uji Duncan 5\% (Numbers followed by the same letters were not significantly different using Duncan 5\%)

Gambar 2. Kandungan Klorofil Padi Hitam Melik Akibat Aplikasi Pupuk Kandang Figure 2. Clorophyll Content of Hitam Melik Black Rice Due to Manure Application

Kandungan klorofil tertinggi terdapat pada perlakuan KT3 (pukan kambing 18,75 g), sedangkan kandungan klorofil terendah terdapat pada perlakuan ST2 (pukan sapi 12,5 g) (Gambar 2). Penelitian yang dilakukan oleh (Herliana et al., 2018) menunjukkan hasil yang sama bahwa aplikasi pupuk kambing menyebabkan kandungan klorofil padi hitam Bantul mencapai 2,11 (lebih tinggi daripada pupuk sapi yang hanya 1,90). Hal ini diduga karena kandungan pupuk kandang kambing yang digunakan cenderung lebih tinggi dibandingkan pupuk kandang lainnya, terutama nitrogen. Seperti telah diketahui bahwa masing-masing unsur hara baik mikro maupun makro esensial berperan penting dan spesifik bagi kelangsungan proses fisiologi pada tanaman (Van Averbeke et al., 2007). Berkaitan dengan hal tersebut, klorofil padi hitam menunjukkan hasil yang berbeda sangat nyata, hal ini mempertegas bahwa kandungan klorofil daun sangat dipengaruhi oleh tingkat ketersediaan unur nitrogen $(\mathrm{N})$, phosphor $(\mathrm{P})$, dan kalium (K) yang terkandung dalam masing-masing pupuk kandang. Menurut (Istanti \& Triasih, 2020) pupuk kandang kambing mengandung 2,325\% $\mathrm{N}$ total, 4,045\% $\quad \mathrm{P}_{2} \mathrm{O}_{5}$; dan 2,977\% $\quad \mathrm{K}_{2} \mathrm{O}$. Kandungan ini hampir $2 \mathrm{x}$ lebih besar daripada kandungan nutrisi dalam pupuk kandang ayam dan pupuk kandang sapi. Sehingga nutrisi yang merupakan komponen klorofil seperti nitrogen akan cenderung meningkatkan kandungan klorofil tanaman (Gambar 2). Hal ini juga ditegaskan oleh pernyataan (BBPADI, 2015) bahwa nutrisi $N$, $P$, dan $K$ yang dibutuhkan tanaman padi berperan sebagai sumber untuk pertumbuhan tanaman, pembentukan anakan sekaligus klorofil untuk proses asimilasi, yang akhirnya memproduksi amilum dan menentukan kualitas beras seperti kandungan amilum, antosianin, dan vitamin B.

Tingginya kandungan klorofil yang terdapat pada pupuk kandang kambing terutama KT3 (18,75 g) menyebabkan hasil berat gabah tanaman padi hitam menunjukkan hasil yang paling tinggi jika dibandingkan dengan perlakuan lain, meskipun secara uji menunjukkan 
hasil yang berbeda tidak nyata. Pola yang jelas dapat diamati pada Gambar 3 yang menunjukkan perlakuan KT3 menghasilkan berat gabah sebesar $4,81 \mathrm{~g}$. Hal ini diduga karena terjadi peningkatan laju fotosintesis pada tanaman akibat meningkatnya kandungan klorofil tanaman padi hitam, sehingga pembentukan dan transfer fotosintat lebih optimal pada perlakuan KT3 dibandingkan perlakuan yang lain.

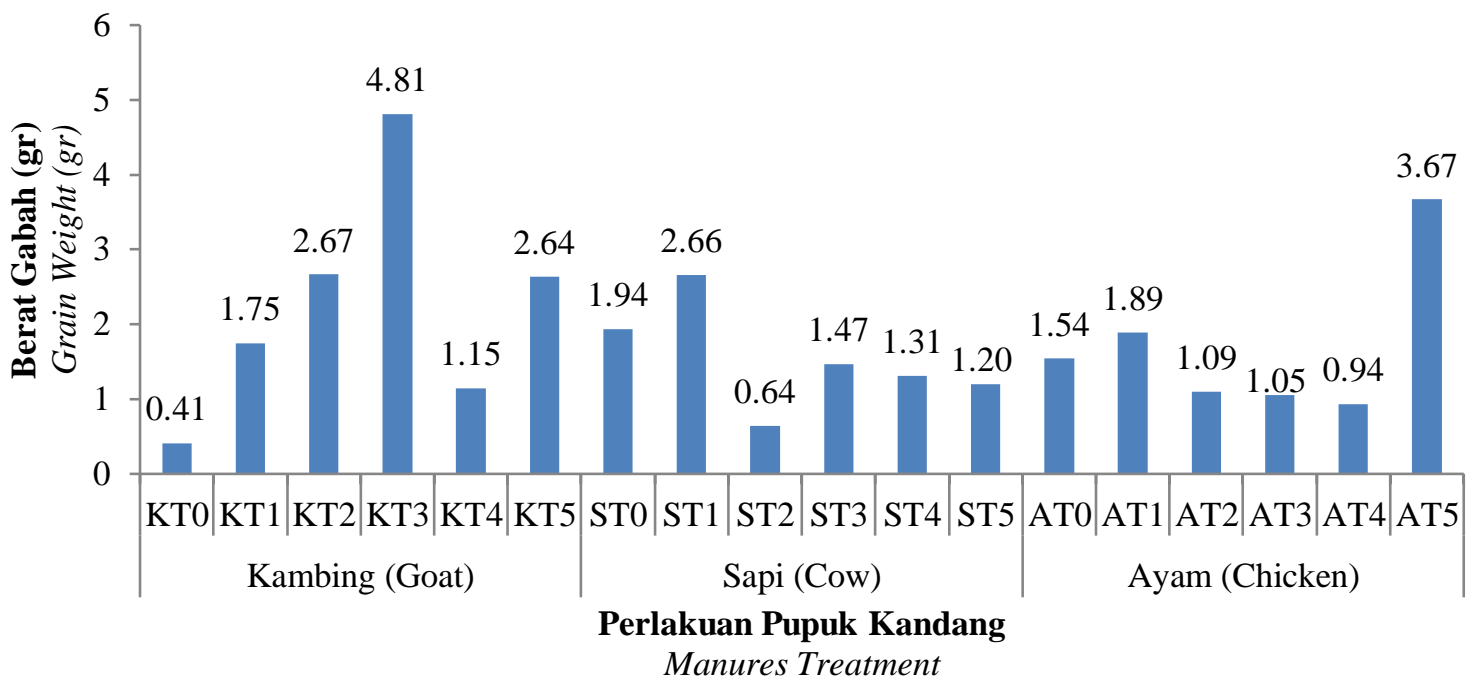

Gambar 3. Berat Gabah Padi Hitam Melik Akibat Aplikasi Pupuk Kandang Figure 3. Gain Weight of Hitam Melik Black Rice Due to Manure Application

$\begin{array}{ccr}\begin{array}{c}\text { Semua } \\ \text { penambahan }\end{array} & \text { perlakuan } & \begin{array}{r}\text { dengan } \\ \text { pupuk }\end{array}\end{array}$ menunjukkan hasil yang lebih baik dibandingkan kontrolnya, hal ini menunjukkan bahwa pemberian beberapa jenis pupuk kandang telah memenuhi kebutuhan tanaman. Proses fotosintesis yang berjalan dengan baik akibat adanya $\mathrm{P}$ juga akan meningkatkan hasil fotosintat yang ditransfer ke dalam biji. Bobot gabah padi sangat berhubungan erat dengan proses fotosintesis yang terjadi pada daun (Azalika et al., 2018) Selain itu menurut (Uchida, 2000), unsur K merupakan aktivator beberapa enzim dalam metabolisme tanaman dan untuk pembentukan ATP (adenosine triphosphate) dan berperan dalam menentukan ukuran gabah. Jika kebutuhan unsur $\mathrm{K}$ tidak memenuhi kebutuhan tanaman, bobot gabah akan berkurang. Lebih lanjut menurut (Supartha et al., 2012) menyatakan kandungan hara mikro dan makro yang terkandung dalam pupuk kandang dapat meningkatan pertumbuhan tanaman dan hasil gabah per rumpun. Dimana dalam penelitian ini pupuk kandang kambing memiliki kandungan $\mathrm{N}$, $\mathrm{P}, \mathrm{K}$ yang lebih tinggi dibandingkan pupuk kandang lain sehingga memberikan hasil yang lebih bagus, terutama pada perlakuan KT3.

\section{KESIMPULAN}

Perlakuan pupuk kandang memberikan hasil yang berbeda sangat nyata hanya pada variabel pengamatan kandungan klorofil, yaitu pada perlakuan pupuk kandang kambing dengan taraf $150 \%$ atau $18,75 \mathrm{~g}$ pupuk kandang kambing (perlakuan KT3) yang menghasilkan 2,67 $\mathrm{mg} / \mathrm{g}$ klorofil. Sedangkan variabel pengamatan laju pertumbuhan dan berat gabah menunjukkan hasil yang berbeda tidak nyata akibat aplikasi pupuk kandang. Akan tetapi perlakuan KT3 cenderung memberikan hasil laju pertumbuhan dan 
berat gabah yang lebih baik dibandingkan perlakuan lain.

\section{DAFTAR PUSTAKA}

Azalika, P. R., Sumardi, \& Sukisno. (2018). Pertumbuhan dan Hasil Padi Sirantau Pada Pemberian Beberapa Macam dan Dosis Pupuk Kandang. JIPI, 20(1), 26-32.

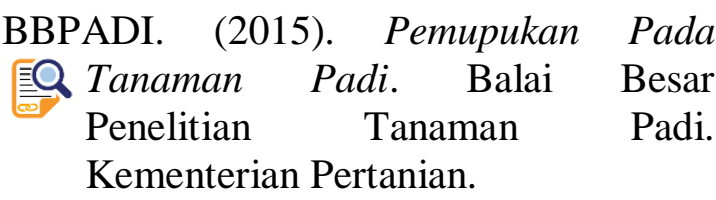

Damanik, M., Bachtiar, M. B., \& Fauzi, E. E H. (2010). Kesuburan Tanah dan Pemupukan.

Gangmei, T. P., \& George, P. J. (2017). Black rice CV. "Chakhao Amubi" (Oryza sativa L.) Response to organic and inorganic sources of nutrients on gowth, yield and gain protein content. Journal of Pharmacognosy and Phytochemistry, 6(4), 550-555.

Herliana, O., Anwar, A. H. S., \& 铇 Widiyawati, I. (2018). Response of Black Rice (Oryza sativa L Indica) to Organic Fertilizer and Seedling Number on Gain Yield, Amylum , Antioxidant, and Thiamin $\mathrm{H}$ ydrochloride Contents. MATEC Web of Conferences, 03032, 0-3.

Istanti, A., \& Triasih, D. (2020). The 住 Gowth Responses of Hitam Melik Black Rice, The Local Variety of Banyuwangi by Manures Application. The 4th International Conference on Agiculture and Life Sciences (ICALS) Retouching Strategy For Exploring Potency of Industrial Crops for Helath in Adapting to The New Normal Era, 69.

Kementerian Pertanian. (2018). Deskripsi
Varietas Padi 2018.

Marwanto, M., Nasiroh, Mucitro, B. G., \& 到 Handajaningsih, M. (2018). Gowth Effects of Combined Application of Cow Manure and Inorganic Nitrogen Fertilizer on Gowth, Yield and Nitrogen Uptake of Black Rice. 21(2), 55-60.

Rekomendasi Pemupukan N, P, dan K 尌 pada Padi Sawah Spesifik Lokasi, 1 (2007).

Sa'adah, I. R., Supriyanta, \& Subejo. EQ (2013). Keragaman Warna Gabah dan Warna Beras Varietas Lokal Padi Beras Hitam (Oryza sativa L.) yang Dibudidayakan oleh Petani Kabupaten Sleman, Bantul, dan Magelang. Vegetalika, 2(3), 13-20.

Suardi, D., \& Ridwan, I. (2009). Beras 镐 Hitam, Pangan Berkhasiat yang Belum Populer. Warta Penelitian Dan Pengembangan Pertanian, 31(2), 9-10.

Supartha, I., Wijana, G., \& Adnyana, G. E (2012). Aplikasi Jenis Pupuk Organik Pada Tanaman Padi Sistem Pertanian Organik. E-Jurnal Agoekoteknologi Tropika (Journal of Tropical Agoecotechnology), 1(2), 98-106.

Uchida, R. (2000). Essential Nutrients for Plant Gowth: Nutrient Functions and Deficiency Symptoms. In Plant Nutrient Management in Hawaii's Soils, Approaches for Tropical and Subtropical Agiculture (pp. 31-55).

Van Averbeke, W., Tshikalange, T. E., \& 伹 Juma, K. A. (2007). The Commodity Systems of Brassica rapa L. subsp. chinensis and Solanum retroflexum Dun. in Vhembe, Limpopo Province, South Africa. Water SA, 33(3 SPECIAL EDICTION), 349-353. 
Yuniarti, R., Wasi'an, W., \& Palupi, T. EQ (2017). Vegetative Phase Characteristic of Tabah Variety of Black Rice Gown in Red-Yellow Podsolic Soil Combine With Organic Materials. Sains Mahasiswa Pertanian, 6(2). 